\title{
THE IMPACT OF TOURISM ON THE BALANCE OF PAYMENTS STABILITY
}

\author{
Mijana Matošević Radić ${ }^{8}$
}

\begin{abstract}
For a long time, the foreign exchange inflow was considered as basic advantage derived from international tourism. This tourism expenditure by foreigners constitutes an injection of liquidity into the economic area which is considered. However, the country can also be faced with the foreign exchange outflow for the purpose of international travel of residents. Although countries in terms of tourism markets are traditionally classified as emissive or receptive market, there is no evidence in the literature about the existence of indicator which can classify them depending on the stability of their tourism balance of trade. The purpose of this paper is to fill this gap, i.e. to develop an indicator that will allow empirical classification of countries, taking into account the data from their tourism balance of trade. With the theoretical elaboration of the tourism balance of trade indicator, in this paper the values of obtained indicators for European Union Member States were calculated, and the impact of tourism on the balance of payments stability in the EU Member States was analysed. The calculation of the tourism balance of trade indicator enable empirical classification of countries according to the stability of their tourism balance of trade, which allows to carry out further analysis of the impact of different aspects of tourism in each of the mentioned groups of countries.
\end{abstract}

Key words: tourism, balance of payments, tourism balance of trade, tourism balance of trade indicator

\section{INTRODUCTION}

Tourism as a worldwide phenomenon, gained the status of an enormously important component of the national economies of many countries.In fact, its economic importance stems from its economic effects, and its contribution to economic development.The importance of tourism for economic development is recognized for its contribution to production, employment and its impact on the balance of payments (Nowak et al., 2007).

The ability of the national economy to benefit fromtourism depends on the availability of investment aimed at developing the infrastructure needed for creating composite tourist product. Due to the fact that the tourist product consists of different goods and services (accommodation, food, transportation facilities, entertainment and safety,among others) tourism is significantly connected with various economic sectors, including transport, retailing, wholesaling, manufacturing,agriculture, arts and

\footnotetext{
${ }^{8}$ Senior Lecturer, University of Split, University Department of Professional Studies, Kopilica 5, 21000 Split, Croatia.
} 
crafts and other services(ProençaiSoukiazis, 2008). Since the tourism in the nationaleconomy has the strongest integration effect among all economic activities, the economic effects of tourism are the result of cohesion power that tourism plays in the national economy.The overall economic impact of tourism is based on the sum of the partial effects of the economic activities that tourism brings together and the synergistic effect resulting from the integration of different activities (Kesar, 2011).

Since tourism is an expenditure-driven economic activity, tourism consumption is the center of the economic measurement of tourism and the foundation of the economic impact of tourism (Mihalič, 2004).Tourism consumption refers to "the total consumption expenditure made by a visitor or on behalf of a visitor for and during his/her trip and stay at the destination" (UNWTO, 2010).

\section{THE EFFECTS OF TOURISM ON THE INTERNATIONAL TRADE}

For a long time, earning foreign currencies was considered to be the main benefit of international tourism. The flow of international tourism produces two main economic effects in the host country: the first one is an income and is linked to the effect of the tourism multiplier, and the secon one is a stabilizing/destabilizing effect on the balance of payments (Candela and Figini, 2012).

Every year, more than one billion people travel abroad for vacations, business reasons or gaining knowledge. The expenditures of these passengers are recorded as an outflow item in the balance of payments of the host country, that is, they are treated as import. On the other hand, expenditures by non-residents in the host countries are recorded as an inflow item, which is seen as export. These two items constitute the tourism balance of trade, which is the part of the current account section of the balance of payments.

However, Wiliams and Shaw (1991) point out thatwe should be careful in determining the real contribution of tourism to the balance of payments. It is crucial to take into account the total tourism balance of trade, ie the difference between income from the inbound tourism and expenditures from the outbound tourism.It is also necessary to take into account the outflow of foreign tourist spending from the economic system which is the result of the import dependence of the economy, unfavorable ownership structure of tourism enterprises which also depends partially on the degree of the domestic production development and its ability to meet tourism needs by domestic production.We should not ignore the demonstration effect which also stimulates import due to the fact that the local population is taking over the consumption pattern of tourists and increasing the demand for imported goods. 
Inbound tourism receipts and outbound tourism expenditures for selected European Unionmember states are shown in Table 1.

Table 1. The tourism balance of trade in selected EU Member States in 2017 (mil. US\$)

\begin{tabular}{|l|r|r|r|}
\hline \multicolumn{1}{|c|}{ Country } & $\begin{array}{c}\text { Inbound tourism } \\
\text { receipts }\end{array}$ & $\begin{array}{c}\text { Outbound tourism } \\
\text { expenditures }\end{array}$ & $\begin{array}{c}\text { Tourism balance } \\
\text { of trade }\end{array}$ \\
\hline Belgium & 13.750 & 22.995 & -9.245 \\
\hline Croatia & 11.128 & 1.399 & 9.729 \\
\hline Germany & 56.173 & 97.597 & -41.424 \\
\hline Greece & 18.820 & 3.308 & 15.512 \\
\hline Netherlands & 20.352 & 22.044 & -1.692 \\
\hline Portugal & 21.099 & 5.647 & 15.452 \\
\hline Poland & 14.083 & 9.567 & 4.516 \\
\hline
\end{tabular}

Source: World Tourism Organization, Yearbook of Tourism Statistics, Compendium of Tourism Statistics and data files

From the data presented in Table 1 it can be seen that the contribution of tourism to the balance of payments differs between countries. Western and northern European countries have a negative tourism balance of trade, while southern and eastern European countries have a positive tourism balance of trade.On a global scale, though, apart from the sun-sea-sand attraction of southern Europe and consequential high level of tourism earnings, the high positive tourism balance of trade tends to belong to less developed countries. Conversely, a deficit in the tourism balance of trade is a characteristic of developed countries (Mihalič, 2004)

Countries are generally categorized as predominantly emissive or predominantly receptive, given the stability of their tourism balance of trade. It is important to distinguish the macroeconomic effect of international tourism in developed countries, which are both significant emitting and receptive areas, from the effect in developing countries, which are mainly significant receptive areas (Candela and Figini, 2012).

The developed countries benefit from both inbound and outbound tourism, since through the consumption of foreign tourists they receive a "new" value in the national product, which directly affects the external balance of the country and creates conditions for faster economic development (Jelusic, 2002). On the other hand, outbound tourism is a negative component of aggregate demand that impedes the development of the national economy. If the sum of imports and outbound tourism expenditures is higher than the sum of exports and Inbound tourism receipts, foreign demand has a negative impact on national income. 
The developing countries often depend on imported foreign goods both for consumption and for investment purposes. Without the positive role played by incoming tourism on the balance of payments, the weight of imports in the balance of payments would be too heavy and would risk to jeopardize the process of development (Candela and Figini, 2012). The financial inflow from tourist arrivals and the outflow from the import of goods in the country reimburses for each other in the balance of payments (Jelusic, 2002).Foreign exchange inflows generated by inbound tourism can be used to finance imports of intermediate and final goods. Inbound tourism plays a significant role in developing countries because it enables them to finance the import of capital and goods, thus starting a virtuous circle of development (Nowak and Sahli, 2007a).

For a number of countries, the foreign exchange inflow from tourism has been the most important item of income in the balance of payments for years and constitutes a very significant factor in economic development.Tourism allows underdeveloped countries as well as developing countries to become more equal in international economic relations with developed countries, which isn't the situation with the balance of trade, ie the exchange of goods (Unković and Zečević, 2005).However, it is important to note that the relative importance of tourism with respect to foreign exchange inflows from tourism is far less important for developed countries (Vanhove, 2012).

However, increased inbound tourism may couse adverse effect on the balance of payments through induced changes in traditional export- and import-competing industries. Countries with floating exchange rates experience upward pressure on the exchange rate, which decreases their export competitiveness and makes imports more attractive (Mihalič, 2013). Although this pressure on the exchange rate completely nullify the positive effect of inbound tourism on the balance of payments, the country where the exchange rate isn't entirely formed on the market and which can "freeze" the exchange rate, can avoid theadverse impact on imports and exports.

\section{THE TOURISM BALANCE OF TRADE INDICATOR}

Although there is an undisputable contribution of tourism to the balance of paymentsstability, the indicator, which allows the classification of countries according to the stability of their tourism balance of trade, wasn't explained in the literature.

For this purpose, a tourism balance of trade indicator is created. The tourism balance of trade indicator is calculated as the ratio of the difference between inbound tourism receipts and outbound tourism expenditure compared to the sum of inbound tourism receipts and outbound tourism expenditure. 


$$
I_{E / R}=\frac{\text { inbound tourism receipts }- \text { outbound tourism expenditures }}{\text { inbound tourism receipts }+ \text { outbound tourism expenditures }}
$$

According to the UNWTO methodology (2018), three basic forms of tourism are distinguished: domestic tourism, inbound tourism and outbound tourism. These forms can be combined in various ways to derive the following additional forms of tourism: internal tourism, national tourism and international tourism. The inbound tourism comprises the activities of a non-resident visitor within the country of reference on an inbound tourism trip. The outbound tourism includes the activities of a resident visitor outside the country of reference, and the international tourism comprises inbound tourism plus outbound tourism, ie the activities of resident visitors outside the country of reference and the activities of non-resident visitors within the country of reference on inbound tourism trips.

Therefore, the tourism balance of tradeindicator can also be calculated as the ratioof the difference between inbound tourism and outbound tourism compered to international tourism.

$$
I_{E / R}=\frac{\text { inbound tourism-outbound tourism }}{\text { international tourism }}
$$

The value of the tourism balance of tradeindicator can range from -1 to $1\left(-1<\mathrm{I}_{\mathrm{E} / \mathrm{R}}<\right.$ 1).

If the value of the indicator is positive $\left(0<\mathrm{I}_{\mathrm{E} / \mathrm{R}}<1\right)$, the country generates higher inbound tourism receipts than the outbound tourism expenditures, so it is concluded that the country is predominantly receptive.If the value of the indicator is negative ($1<\mathrm{I}_{\mathrm{E} / \mathrm{R}}<0$ ), the country achieves higher outbound tourism expenditures than inbound tourism receipts, so the country is considered to be predominantly emissive.If the value of the indicator is close to zero $\left(\mathrm{I}_{\mathrm{E} / \mathrm{R}} \approx 0\right)$, the country has approximately the same values of inbound tourism receiptsand the outbound tourism expenditures, so the country is considered to be emissive/receptive (and in this case, the impact of tourism on the balance of payments stability is neutral in that country).

\section{THE IMPACT OF TOURISM ON THE BALANCE OF PAYMENTS STABILITY IN EUROPEAN UNION MEMBER STATES}

The World Tourism Organization (UNWTO) data taken from the World Bank database (WDI database) were used to calculate tourism balance of trade indicator for European Union member states. According to the theoretical definition of indicators, two time series were used: receipts from inbound tourism and expenditures from outbound tourism. Data coverage is from 2010 to 2017. 
Table.2. The values of the tourism balance of tradeindicator in selected EU Member States

\begin{tabular}{|c|c|c|c|c|c|c|c|c|}
\hline & & & & 3 & 4 & 5 & 16 & \\
\hline & 0,299 & 0,304 & & & 0,307 & 0,286 & & 0,270 \\
\hline & & & & & & & & \\
\hline & & & & & & & & \\
\hline & & & & & & & & \\
\hline & & & & & & & & \\
\hline & & & & & & & & \\
\hline & & & & & & & & \\
\hline & & & & & & & & \\
\hline & & & & & & & & \\
\hline & & & & & & & & \\
\hline & & & 02 & & 268 & & 52 & $-0,269$ \\
\hline & & & & & & & & \\
\hline & & & & & & & & \\
\hline & & & & & & & & \\
\hline & & & & & & & & \\
\hline & & & & & & & & \\
\hline & & & & & & & & \\
\hline & & & & & & & & \\
\hline & & & & & & & & \\
\hline & & & & & & & & \\
\hline & & & & & & & & \\
\hline & & & & & & & & \\
\hline & & & & & & & & \\
\hline & & & & & & & & \\
\hline & & & & & & & & \\
\hline & & & & & & & & \\
\hline & & & & & & & & \\
\hline GBR & $-0,291$ & $-0,240$ & $-0,204$ & $-0,183$ & $-0,154$ & $-0,158$ & $-0,173$ & $-0,16$ \\
\hline
\end{tabular}

Source: World Tourism Organization, World Bank database (WDI database)

From the data presented in Table 2 it can be seen that:

- the group of predominantly receptive countries consists of: Austria, Bulgaria, Croatia, Cyprus, Czech Republic, Estonia, France, Greece, Hungary, Ireland, Italy, Latvia, Luxembourg, Malta, Poland, Portugal, Slovenia, Spain,

- the group of predominantly emissive countries consists of 5 countries: Belgium, Denmark,Finland, Germany, United Kingdom 
- the group of emissive / receptive countries consists of 5 countries as follows: Lithuania, Netherlands, Romania,Slovak Republic, Sweden.

If it is comparing the balance of trade, which is the largest component of a country's balance of payments, and tourism balance of trade in different groups of countries, it can be noted that tourism has different effects on the balance of payments stability.Figure 1 shows the relationship between the trade balance and the tourism balance of trade in a group of predominantly receptive countries.

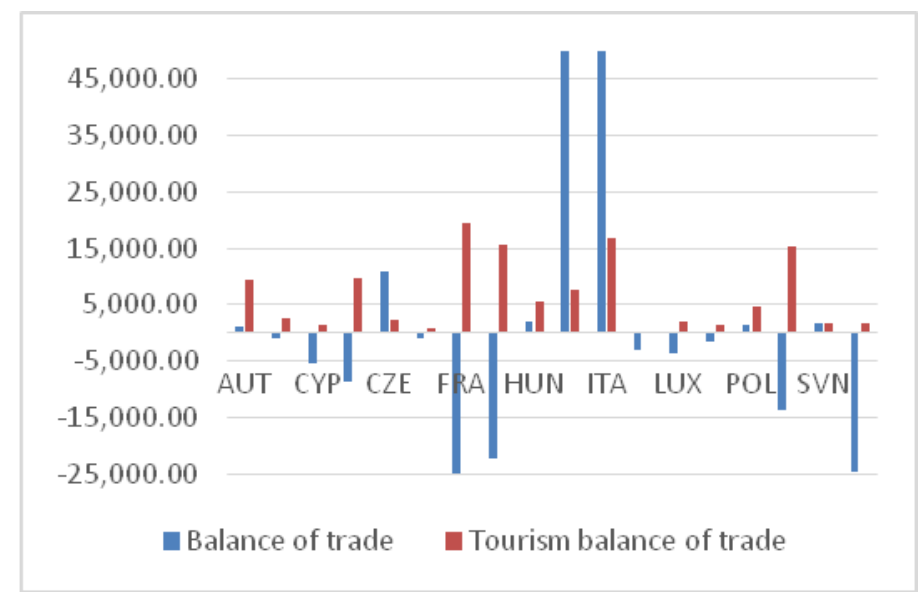

Fig. 1. The relationship between the trade balance and the tourism balance of trade in predominantly receptive countries

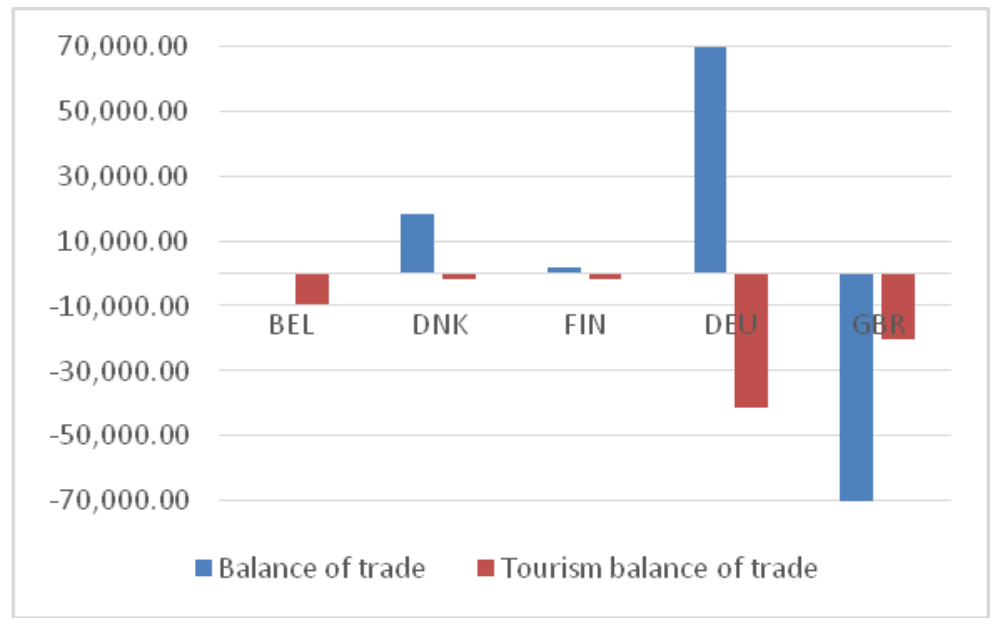

Fig.2. The relationship between the trade balance and the tourism balance of trade in predominantly emissive countries 
Analyzing the Figure 1, it can be seen that some receptive countries have balance of trade deficitand othercountrieshave balance of trade surplus. Countries that have balance of trade deficit and in the mean time, tourism balance of trade surplus, used to cover the import of goods with inbound tourism receipts. On the other hand, countries that have both balance of trade and tourism balance of trade surplus, developing tourism increases the overall positive balance in foreign relations.

Figure 2 shows relationship between the trade balance and the tourism balance of trade in a group of predominantly emissive countries. The emissive countries, which are mostly developed countries, have a balance of trade surplus, and in their case a negative balance of tourism balance of trade diminishes the positive balance of balance of payments.It should be noted that only the United Kingdom has a deficit of both the balance of trade and the tourism balance of trade, suggesting that the negative balance of the tourism balance of trade further stimulates the negative balance of balance of payments.

\section{CONCLUSION}

The contribution of tourism to the balance of payments is cited as one of the most significant economic benefits of tourism. The development of the tourism balance of tradeindicators enables the countries to be empirically classified according to the stability of their tourism balance.The empirical classification of countries according to the stability of their tourism balance is the basis for further researches in different fields.

By classifying countries into emissive, receptive and emissive/receptive countries, their common characteristics are highlighted, which allows them to be analyzed as homogeneous groups.Analyzing the impact of the tourism balance on the balance of payments, it is noted that there are two characteristic effects in both groups of emissive and receptive countries, depending on whether the balance of payments is in surplus or in deficit.Depending on it, tourism can increase the deficit, increase the surplus or contribute to the stability of the balance of payments. 


\section{REFERENCES}

1. Candela, G., Figini, P. (2012). The Economics of Tourism Destinations. Berlin, Heidelberg: Springer

2. Jelušić, A. (2002). Uloga turizma u uravnoteženju platnobilančnih odnosa Republike Hrvatske. Ljubljana: Univerza v Ljubljani, Ekonomska fakulteta

3. Kesar, O. (2011). Turističkapotrošnjaiekonomskiučinciturizma. in: Čavlek, N. i sur. (2011). Turizam: ekonomskeosnoveiorganizacijskisustav. Zagreb: Školskaknjiga

4. Mihalič, T. (2004). Tourism and Economic Development Issues. in: Sharpley, R., Telfer, D. J. (2004). Tourism and Development, Concepts and Issues. Aspects of Tourism, Chanel View Publications

5. Mihalič, T. (2013). Economic Impact of Tourism, Particularly its Potential Contribution to Economic Development.in: Tisdell, C. A. (ed.) (2013) Handbook of tourism economic - Analysis, New Applications and Case Studies. Singapore, World Scientific Publishing

6. Nowak, J. J., Sahli, M. (2007a). Coastal tourism and „Dutch disease“ in a small island economy. Tourism Economics, No. 13, Vol. 1, p. 49 - 65

7. Nowak, J. J., Sahli, M., Cortés-Jiménez, I. (2007). Tourism, capital goods import and economic growth: theory and evidence for Spain. Tourism Economics, Vol. 13 (4), p. 515 - 536.

8. Proença, S., Soukiazis, E. (2008). Tourism as an economic growth factor: a case study for Southern European countries. Tourism Economics, Vol. 14 (4), p. $791-806$.

9. Unković, S., Zečević, B. (2005). Ekonomika turizma.2nd edition, Beograd: Centar za izdavačku delatnost Ekonomskog fakulteta u Beogradu

10. Vanhove, N. (2012). The Economics of Tourism Destinations. 2nd Edition, London: Routledge Taylor \& Francis Group

11. Williams, A. M., Shaw, G. (1991). Tourism and Economic Development, Western European Experiences. 2nd edition, London: Belhaven Press, A division of Printer Publishers

12. World Tourism Organization (UNWTO) (2010). TSA data around the world, worldwide summary. Statistics and Tourism Satellite Account (TSA)

Programme, Madrid, available at: http://statistics.unwto.org/sites/all/files/pdf/tsa_data.pdf

13. World Tourism Organization (UNWTO) (2019). Understanding tourism: basic glossary, available at:

http://cf.cdn.unwto.org/sites/all/files/docpdf/glossaryenrev.pdf 